\title{
[ CONTEnTs ]
}

Introduction

\section{PART I \\ The Life}

1. "When I Was in My Sins," 1181-1205 3

2. The Penitent from Assisi, 1206-1209 19

3. The Primitive Fraternity, 1209-1215 34

4. Expansion and Consolidation, 1216-1220 54

5. Francis Returns Home, 1220-1221 72

6. Rules and Retirement, 1221-1223 91

7. The Way of the Cross, 1223-1225 110

8. From Penitent to Saint, 1225-1226 126

$\begin{array}{ll}\text { For Further Reading } & 143\end{array}$ 


\section{PART II}

Sources and Debates

Preliminary Note

List of Abbreviations

On the "Franciscan Question"

On Chapter 1

On Chapter 2

On Chapter 3

On Chapter 4

On Chapter 5

On Chapter 6

On Chapter 7

On Chapter 8

Index 